\title{
Simulation of the evolution of Breidamerkurjökull in the late Holocene
}

\author{
Faezeh M. Nick, ${ }^{1}$ Johannes van der Kwast, ${ }^{2}$ and Johannes Oerlemans ${ }^{1}$ \\ Received 20 February 2006; revised 13 July 2006; accepted 22 September 2006; published 23 January 2007.
}

[1] We have simulated the advance and retreat of Breidamerkurjökull, a tidewater glacier in Iceland, by means of a one-dimensional numerical ice flow model. The calculations were done with two different schemes for iceberg calving, the flotation model and the water depth model. The model simulates the glacier history by an advance into a lake filled by unlithified sediments without the occurrence of calving, followed by a retreat with calving into the excavated lake. The results indicate that the flotation model is not capable of producing the observed glacier retreat into deep water well, whereas the water depth model provides a glacier evolution similar to the observed retreat. The water depth model predicts that Breidamerkurjökull will retreat out of the lake after approximately 100 years under the present climatic conditions.

Citation: Nick, F. M., J. van der Kwast, and J. Oerlemans (2007), Simulation of the evolution of Breidamerkurjökull in the late Holocene, J. Geophys. Res., 112, B01103, doi:10.1029/2006JB004358.

\section{Introduction}

[2] Iceberg calving from tidewater glaciers is a dominant ablation mechanism, which can allow much larger volumes of ice to be lost in a short time than would be possible through surface ablation [Van der Veen, 1996]. Some attempts have been made to find a general calving law for any grounded calving glacier in the world; nevertheless, the physical processes that control the calving rate have remained elusive. Two empirical formulations have been proposed to describe calving. The first one is the water depth model, in which the averaged calving rate is linearly related to the water depth at the terminus [Brown et al., 1982; Pelto and Warren, 1991]. Meier and Post [1987] pointed out that the water depth model is not valid for the fast retreat of the Columbia Glacier since the approach to flotation may become the controlling factor. Van der Veen [1996] argued that the water depth model is relevant only for glaciers that are almost in steady state. He proposed the height-above-buoyancy model in which the position of the calving front is controlled by local geometry. Vieli et al. [2001] suggested a modified flotation criterion for this model, which requires a frontal ice thickness exceeding the flotation thickness by a small fraction $q$. In this case, the frontal ice thickness $H_{c}$ is given by

$$
H_{c}=-\frac{\rho_{w}}{\rho_{i}}(1+q) d
$$

where $\rho_{w}$ is the water density, $\rho_{i}$ is the glacier ice density and $d$ is the bed elevation at the terminus. Vieli et al. [2001]

\footnotetext{
${ }^{1}$ Institute for Marine and Atmospheric Research, Utrecht University, Utrecht, Netherlands.

${ }^{2}$ Department of Physical Geography, Faculty of Geosciences, Utrecht University, Utrecht, Netherlands.

Copyright 2007 by the American Geophysical Union. 0148-0227/07/2006JB004358\$09.00
}

presented a two-dimensional ice flow model, including the flotation model. Their model simulates a cycle of slow advance and rapid retreat across a basal depression on a synthetic bed with the deepest point at $100 \mathrm{~m}$ below sea level. Nick and Oerlemans [2006] carried out a comparison between two calving models, the water depth model and the flotation model, by applying them to two idealized basal profiles. Their study pointed out that the flotation model fails to create a large glacier terminating in deep water. In this study, we make a further contribution to the comparison of these two calving models. Instead of looking at idealized bed profiles, we have tried to reproduce the late Holocene history of Breidamerkurjökull, Iceland (Figure 1). We used a one-dimensional flow line model with varying lateral geometry.

[3] We simulated the advance of the glacier from no ice to its maximum length, followed by a retreat into a tidal inlet, which was excavated entirely during the glacier advance. The model assumes that there is no calving during the glacier advance as the inlet is filled by unlithified sediments [Evans and Twigg, 2002; Björnsson, 1996; Boulton et al., 1982]; on the other hand, the simulated glacier retreat is accompanied by calving into the inlet.

[4] Retreat of Breidamerkurjökull has been well documented on maps since 1903 and by aerial photographs since 1945 (Figure 1). A series of aerial photos covering the glacier front exist for 11 dates from 1945 to 2003 . We applied photogrammetric analysis to these aerial photographs to obtain measurements of changes in the length, speed and surface altitude at the glacier front. The results of this analysis were then used to validate the simulations with the numerical model.

[5] In this paper, we first discuss the recent history of Breidamerkurjökull (section 2). In section 3, we describe the numerical ice flow model and the model input, followed by an overview of the methods applied to the aerial photographs. Section 4 presents the numerical model results and a comparison between model results and the data 


\section{$\underline{a}$}

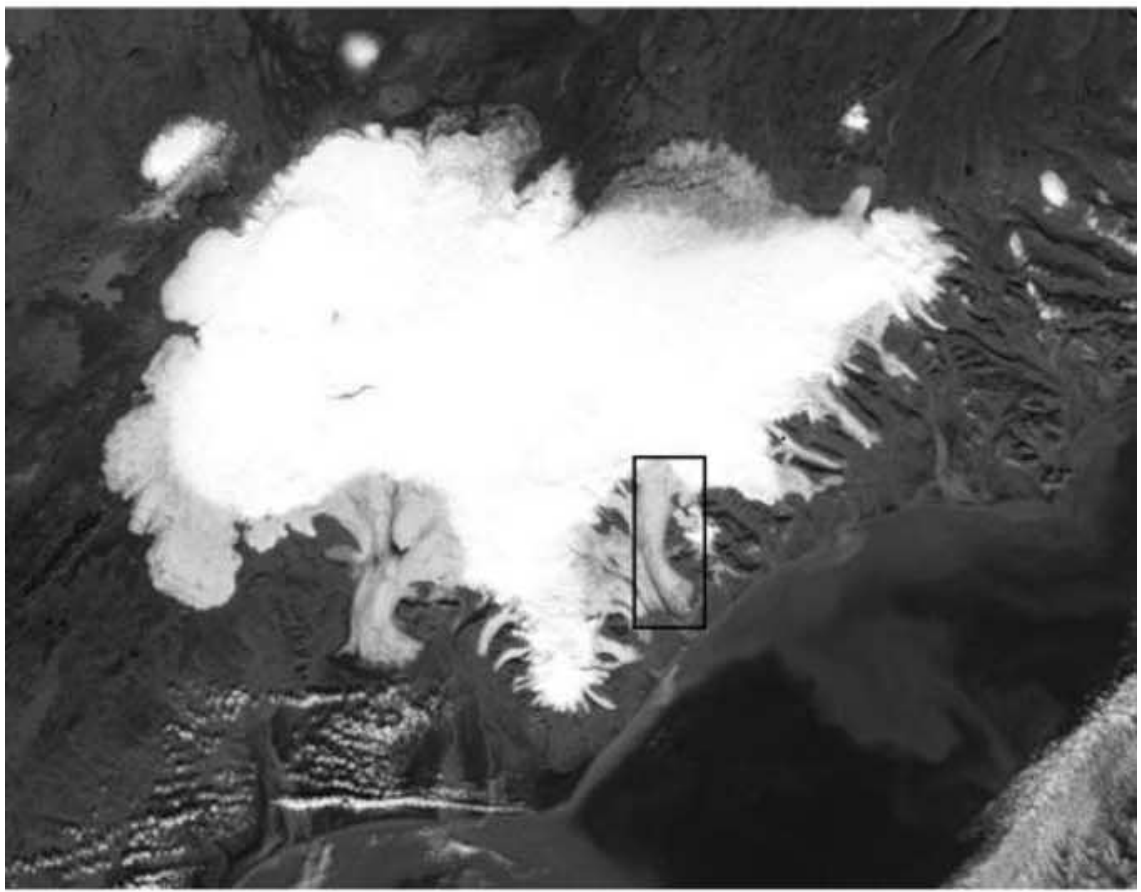

$\underline{b}$
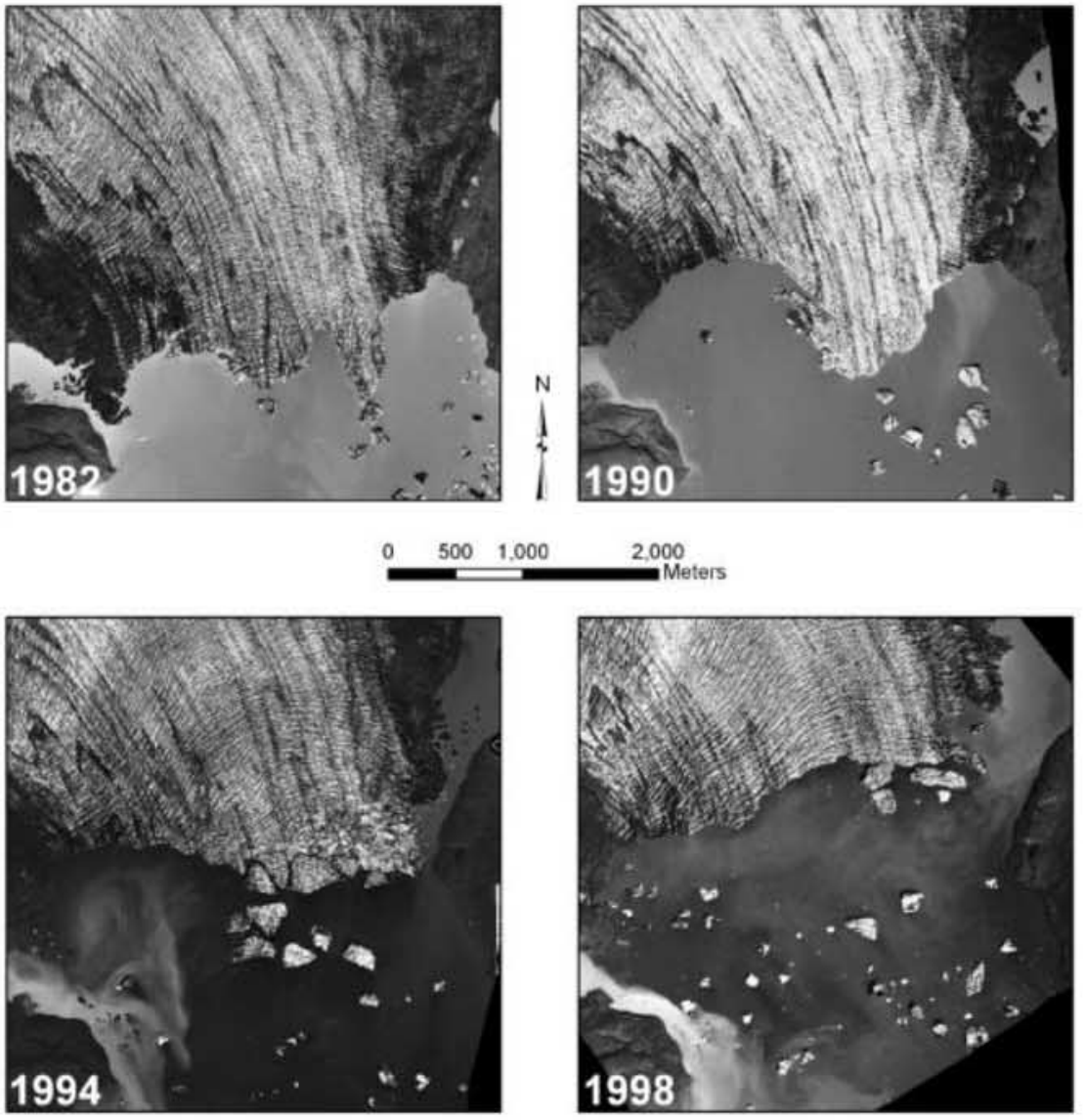

Figure 1. (a) MODIS satellite image of Vatnajökull, Iceland. The box indicates the location of Breidamerkurjökull. (b) Four selected orthorectified aerial photographs of the glacier front, showing the terminus variations of the glacier from 1982 to 1998. 


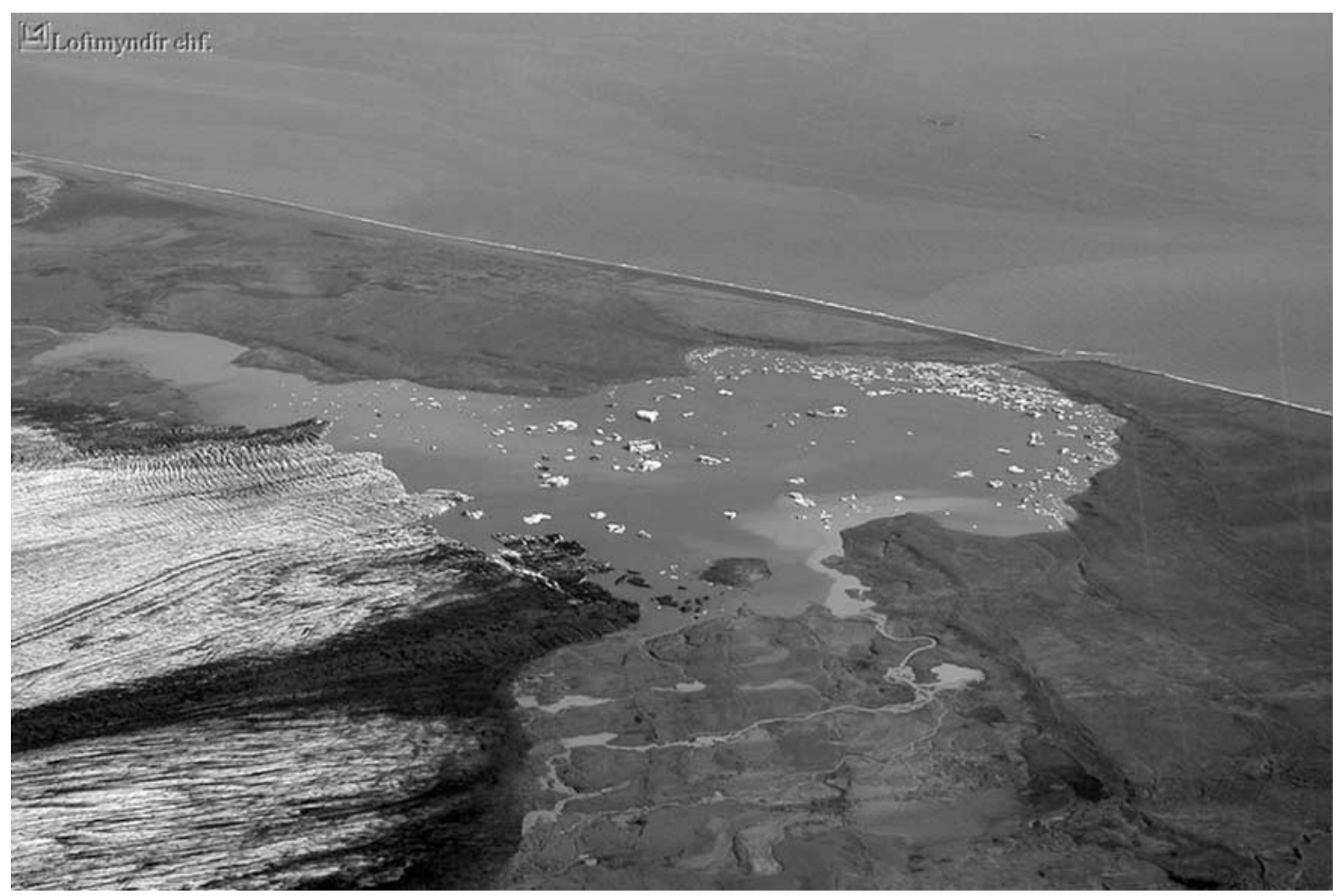

Figure 2. Glacier terminus of Breidamerkurjökull, the lake Jökulsárlón and the outlet river Jökulsá. Photo by Loftmyndir ehf, 22 August 2003.

acquired from stereophotographs. We further discuss the model results and predict the future behavior of the glacier (section 5).

\section{Breidamerkurjökull}

[6] Breidamerkurjökull is the most active outlet glacier of Vatnajökull, the largest ice cap in Iceland. It began to retreat from its Little Ice Age maximum extent in 1890. The glacier calves into a proglacial lake, Jökulsárlón, which is a tidal inlet and was excavated during the glacier advance. During the Little Ice Age, the glacier ran over the vegetation and farms and advanced about $15 \mathrm{~km}$ [Björnsson, 1996]. Prior to the advance, the inlet was filled with unlithified sediments. The glacier advance removed the unlithified sediments from the inlet basin. Records of the glacier's activity indicate that the glacier has surged 11 times between 1794 and 1969, with 6 to 38 years between the surges [Björnsson et al., 2003]. Since 1930, the glacier has retreated into the lake a distance of about four kilometers. Because of this, the surface area of the lake has grown to $15 \mathrm{~km}^{2}$. With the present retreat rate of the glacier, the lake is expanding about $0.5 \mathrm{~km}^{2} \mathrm{yr}^{-1}$ [Björnsson et al., 2001]. As the glacier is retreating into the lake, most of the sediments are deposited in the lake instead of being transported by the Jökulsá river to the coastline. Therefore the sediment transport by the river is not enough to compensate for erosion of the coastline (Figure 2). Many of the studies of the glacier and its proglacial lake are motivated by this coastline retreat and the threat to the highway across Breidamerkursandur.
[7] Björnsson et al. [2001] have done comprehensive work that describes the ice fluxes and calving rate and simulates the glacier retreat since the formation of the lake in the 1930s.

\section{Methods and Materials}

\subsection{Model Description}

[8] We used a one-dimensional numerical ice flow model. The model is a finite difference, time-dependent ice flow model that calculates the surface evolution and ice velocity along the central flow line [Oerlemans, 2001]. The threedimensional geometry is implicitly taken into account by the parameterization of the cross-sectional geometry for each grid point. The evolution of the ice surface is determined by the vertically and laterally integrated continuity equation for incompressible ice [Van der Veen, 1999]:

$$
\frac{\partial H}{\partial t}=-\frac{1}{W} \frac{\partial(W H U)}{\partial x}+B
$$

where $t$ is time, $x$ is distance along the flow line, and $B$ is the surface mass balance. $H, W$ and $U$ are the ice thickness, the glacier width and the ice velocity, respectively. The ice velocity is expressed as a velocity averaged over the cross section and consists of a deformational part $U_{d}$ and a basal sliding part $U_{s}$. The shear stress is related to the strain rate according to Glen's flow law for plane shear [Glen, 1955]. This yields [Paterson, 1981]

$$
U_{d}=f_{d} H S_{d}^{3}
$$



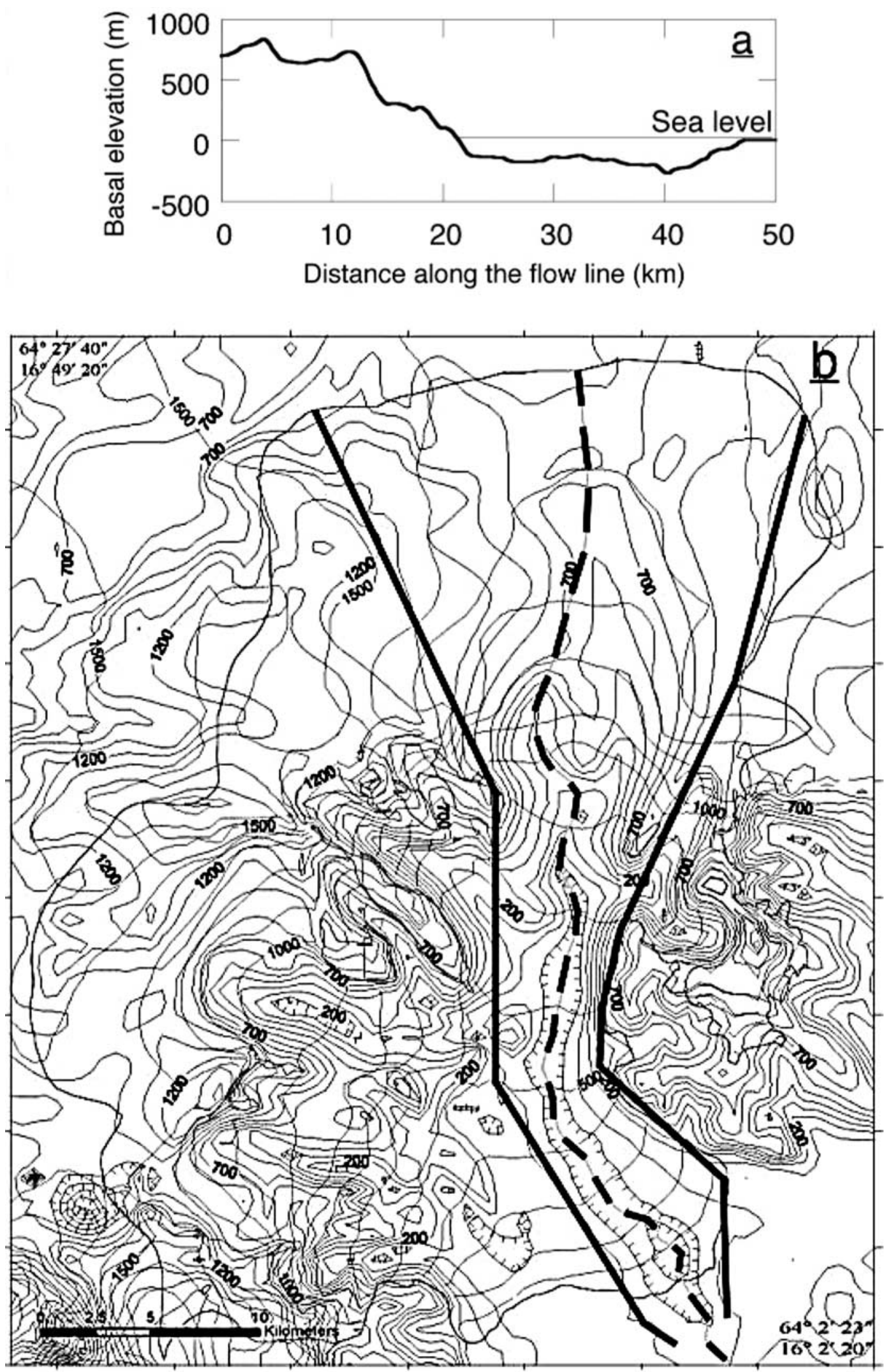

Figure 3. (a) Basal elevation of Breidamerkurjökull along its central flow line from the summit dome of Vatnajökull to its snout at its Little Ice Age maximum extent. Data from radio echo sounding in 1991. (b) Glacier geometry. The dashed line indicates the central flow line. (Data for both figures were provided by H. Björnsson and F. Pálsson.) 

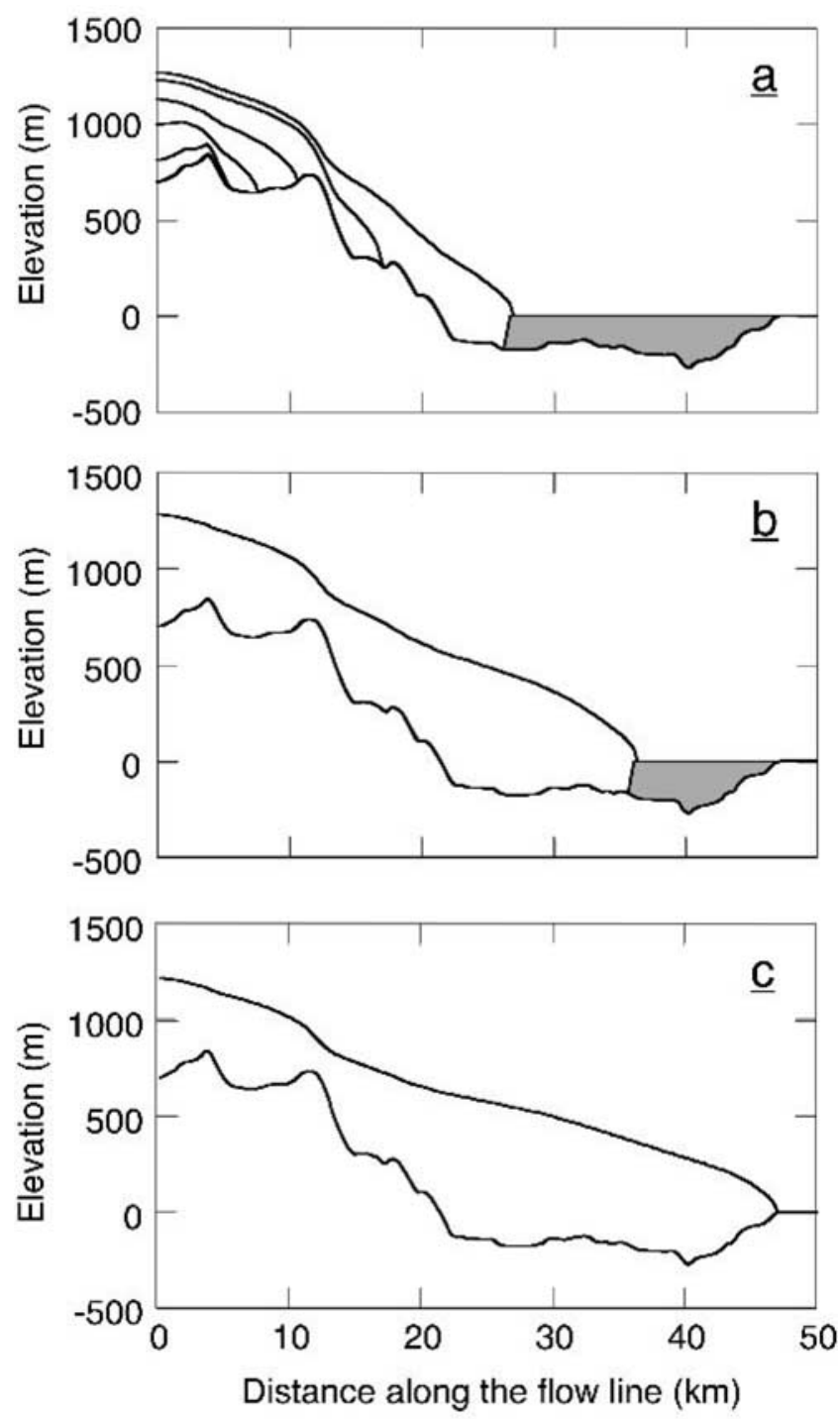

Figure 4. The simulated surface profiles along the central flow line of Breidamerkurjokull. (a) As the glacier grows, the sedimentation bank in front of the glacier (gray area in Figures $4 \mathrm{a}$ and $4 \mathrm{~b}$ ) is pushed forward. (b) Glacier advance excavated the basin of the lake from unlithified sediments. (c) Glacier surface profile at its maximum extent.

in which $f_{d}$ is a temperature-dependent flow parameter and $S_{d}$ is the driving stress, which is defined as

$$
S_{d}=-\rho_{i} g H \frac{\partial h}{\partial x}
$$

where $h$ is the ice surface elevation and $g=9.8 \mathrm{~m} \mathrm{~s}^{-2}$ is the gravitational acceleration. The flow parameter, $f_{d}=0.75 \times$ $10^{-16}$, suggested by Björnsson et al. [2001] for Breidamerkurjokull, is used in this model.

[9] A Weertman-type sliding law, supported by the experimental work of Budd et al. [1979], is applied in the model:

$$
U_{s}=\frac{f_{s}^{\prime} S_{b}^{3}}{\rho_{i} g H-P}
$$

where $S_{b}$ is the basal stress, $P$ is the basal water pressure, and $f_{s}^{\prime}$ is an empirical parameter. We do acknowledge that the basal water pressure affects the sliding velocities [Budd et al., 1979]; however, for simplicity, we neglected this contribution that the basal water pressure makes to the effective basal stress. Making the assumption that $P$ is proportional to the ice thickness and that the basal stress equals the driving stress, the vertical mean ice velocity $U$ can then be expressed as

$$
U=U_{d}+U_{s}=f_{d} H S_{d}^{3}+\frac{f_{s} S_{d}^{3}}{H}
$$

in which $f_{s}$ is the sliding parameter [Oerlemans, 2001].

[10] Incorporating the longitudinal deviatoric stresses in the calculation of the deformation velocity results in an increase of the basal sliding velocity and a concave surface profile for ice sheets [Van der Veen, 1986]. These stresses have a negligible effect on the evolution of grounded glaciers. Van der Veen and Whillans [1993] computed stresses acting on Columbia Glacier, a grounded calving glacier in Alaska. Their calculations showed that the basal stress opposes nearly all of the driving stress and the lateral stresses and the gradients in longitudinal stress maintain a minor resistance to the flow of the glacier. Moreover, there
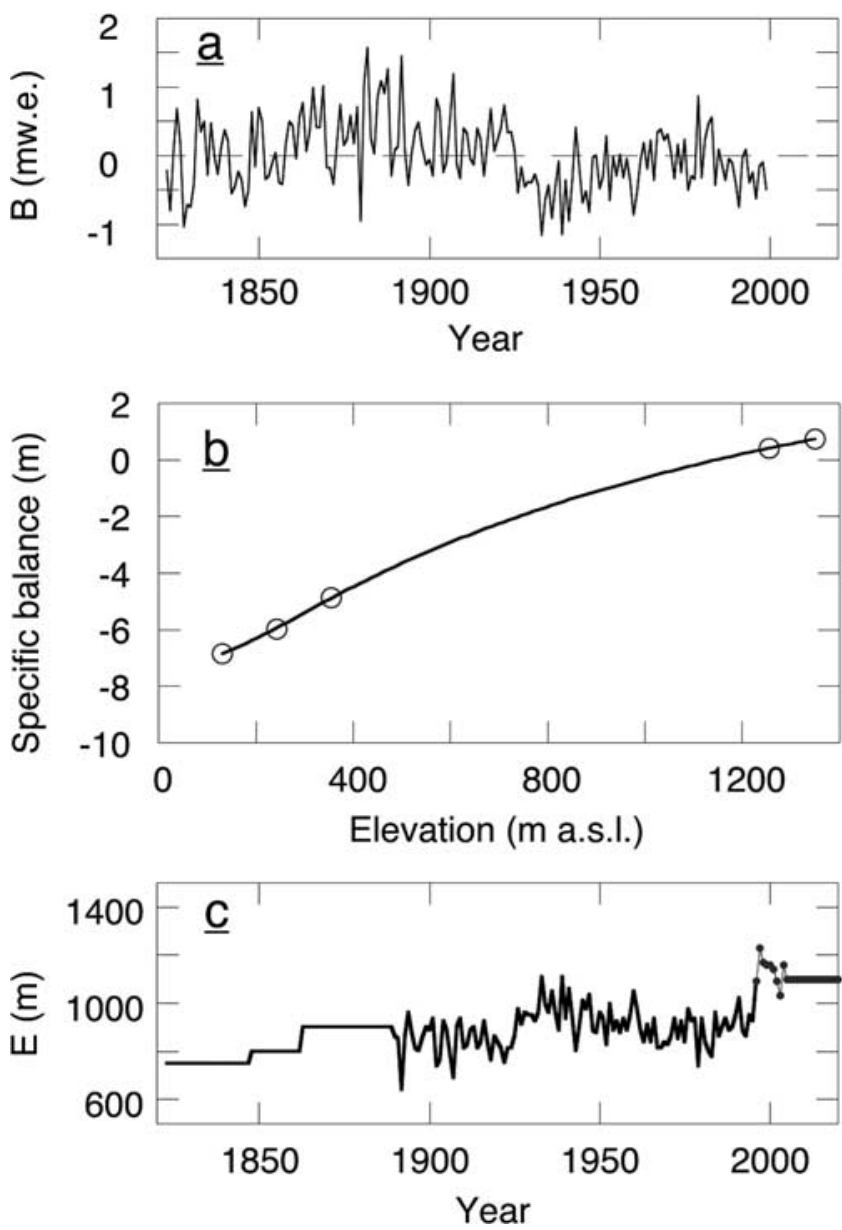

Figure 5. (a) Simulated mean specific mass balance of Vatnajökull, 1825-1998. (b) Observed annual mass balance on Breidamerkurjökull, 1998. (c) Estimated $(<1890)$, calculated (1890-1998), and observed (1998-2004) values of $E$ are used to reproduce the glacier advance and retreat. Mean value of $E$ over $1998-2004, E=1100 \mathrm{~m}$, is used to simulate the future behavior of the glacier. 
Table 1. Properties of the Aerial Photographs Covering the Glacier Front and the Lake

\begin{tabular}{lccccccc}
\hline Year & Date & Type & Focal Length, mm & Number of Photos & Resolution & Scale & Source \\
\hline 2003 & Aug 22 & color & 153 & 3 & $21 \mu \mathrm{m}$ & $1: 30,000$ & Lofmyndeir \\
1998 & Aug 9 & B/W & 153.15 & 6 & 1200 dpi & $1: 30,000$ & Landmælingar Íslands \\
1994 & Aug 22 & B/W & 152.82 & 6 & 1200 dpi & $1: 30,000$ & Landmælingar Íslands \\
1992 & Aug 4 & B/W & 151.78 & 2 & 1200 dpi & $1: 30,000$ & Landmælingar Íslands \\
1991 & Aug 21 & infrared & 151.78 & 2 & 1200 dpi & $1: 30,000$ & Landmælingar Íslands \\
1990 & Sep 4 & B/W & 151.78 & 3 & 1200 dpi & $1: 30,000$ & Landmælingar Íslands \\
1982 & Aug 20 & B/W & 151.78 & 3 & 1200 dpi & $1: 30,000$ & Landmælingar Íslands \\
1964 & Sep 9 & B/W & 115.06 & 2 & 1200 dpi & $1: 30,000$ & Landmælingar Íslands \\
1961 & Jul 4 & B/W & 153.55 & 2 & 1200 dpi & $1: 30,000$ & Landmælingar Íslands \\
1954 & Sep 15 & B/W & 115.02 & 2 & 1200 dpi & $1: 30,000$ & Landmælingar Íslands \\
1945 & Aug 30 & B/W & 153.04 & 2 & 1200 dpi & $1: 30,000$ & Landmælingar Íslands \\
\hline
\end{tabular}

is no evidence indicating that longitudinal deviatoric stresses are important in controlling the large-scale flow of any glacier [Van der Veen, 1997]. Therefore we did not include these stresses in our model.

[11] Equation (2) was solved on a grid along the flow line. There are 250 grid points along the central flow line, initially at a uniform distance of $\Delta x=200 \mathrm{~m}$. This distance changes with every time step as a new grid is defined to fit the new glacier [Nick and Oerlemans, 2006]. We used an explicit scheme for time integration. The time step is 0.001 year, which is small enough to satisfy the stability criterion [Smith, 1978] for different values of $\Delta x$. The use of variable widths at each grid point parameterizes the converging or diverging flow along the flow line.

[12] The boundary condition at the downstream end of the glacier depends on the type of calving model used. For the flotation model, the glacier thickness at the terminus cannot be less than a given limit $H_{c}$. Vieli et al. [2001] defined the thickness $H_{c}$ as a small fraction $q$ of the flotation thickness plus the flotation thickness:

$$
H_{c}=-\frac{\rho_{w}}{\rho_{i}}(1+q) d
$$

We estimated the fraction $q=0.09$ from the observed frontal thickness along the central flow line of Breidamerkurjökull. To satisfy this criterion in the model, the position of the terminus is shifted at each time step to the point where the ice thickness is equal to $H_{c}$. The actual position of the terminus is determined by interpolating between values of two neighboring grid points with ice thicknesses larger and smaller than $H_{c}$. Thereafter, new grid points are defined to fit the updated glacier length and the ice thickness is calculated for the new grid points using linear interpolation.

[13] In the water depth model the calving rate $U_{c}$ is linearly related to the water depth at the terminus:

$$
U_{c}=\alpha d
$$

The coefficient $\alpha=2.6$ was suggested by Björnsson et al. [2001] for Breidamerkurjökull. The terminus position changes in response to the imbalance between the ice velocity and the calving rate [Meier, 1994, 1997], as follows:

$$
\frac{d L}{d t}=U_{f}-U_{c}
$$

where $L$ is the glacier length. At each time step, the position of the terminus is obtained from the ice velocity at the terminus $U_{f}$ minus the calving rate and the new grid points are adjusted to fit the updated glacier length.

\subsection{Model Input}

[14] Figure 3a shows the basal elevation of the glacier along the central flow line (provided by H. Björnsson and F. Pálsson (unpublished data, 2004)). Figure 3b depicts the approximate glacier width along the central flow line. The glacier width was taken from a topographic map in a way that conforms to the surface elevation distribution.

[15] During the advance scenario, the basal elevation at the glacier front does not get below sea level. An assumed sedimentation bank levels off the ground with the sea level in front of the glacier. Hence no calving occurred. This sedimentation bank is pushed forward during each time step as the glacier advances (gray areas in Figure 4).

[16] We used a simplified mass balance function for Breidamerkurjökull in which the mass balance $B$ depends linearly on altitude:

$$
B(x)=\beta(h(x)-E) \Delta x
$$

where $\beta$ is a constant balance gradient and $E$ is the equilibrium line altitude. For the advancing scenario, $E$ was chosen so that in the model the glacier grows from ice-free conditions to a length of $47 \mathrm{~km}$, which represents the Little Ice Age maximum glacier extent in 1890 . For the retreating phase, $E$ was derived from the observed mass balance data. To define $E$ for each year, the annual specific mass balance variation [De Ruyter de Wildt, 2002] is applied to a reference mass balance function of height [Björnsson et al., 1998; Dowdeswell et al., 1997; Björnsson et al., 2002]. De Ruyter de Wildt [2002] reconstructed the specific mass balance variation of Vatnajökull from 1825 until 1998, based on the temperature data from a site close to Breidamerkurjökull

Table 2. Topographical Maps of Breidamerkurjökull, Southeast Iceland

\begin{tabular}{llcc}
\hline Year & Source & Scale & Projection \\
\hline 1998 & Department of Geography, University of Glasgow & $1: 30,000$ & UTM 28N,International ellipsoid, Hjörsey 1955 \\
1965 & Department of Geography, University of Glasgow & $1: 30,000$ & Lambert conformal conic projection, Iceland grid \\
1945 & Department of Geography, University of Glasgow & $1: 30,000$ & Lambert conformal conic projection, Iceland grid \\
\hline
\end{tabular}




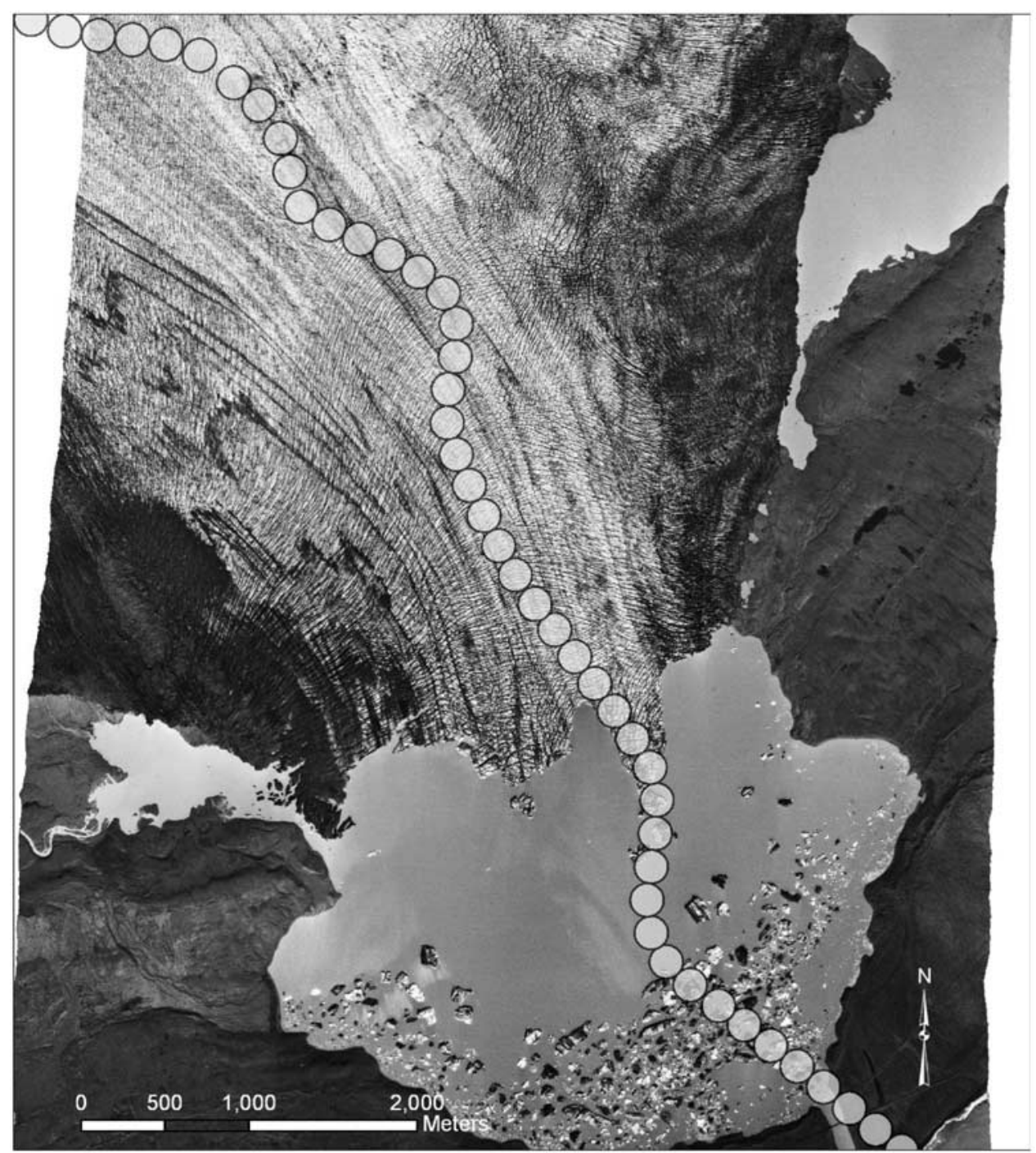

Figure 6. Orthorectified aerial photograph of the glacier front. Circles with a 100-m radius were defined along the central flow line; the averaged ice thickness was determined in each circle.

(Figure 5a). The observed surface mass balance in 1998 on Breidamerkurjökull is shown in Figure 5b. A smooth curve fit for the 1998 measurements serves as a reference mass balance function of height. The model uses the constructed $E$ (Figure $5 \mathrm{c}$ ) to simulate the glacier advance and to provide a proper initial surface profile for the retreating phase. The glacier retreat is forced by applying the calculated $E$ from 1890 until 1998 and the observed value of $E$ from 1998 until 2004, provided by H. Björnsson and F. Pálsson (unpublished data, 2004) (dotted line in Figure 5c). The mean value of $E$ over $1998-2004, E=1100 \mathrm{~m}$, is then used to predict the future behavior of the glacier.

\subsection{Aerial Photography}

[17] Aerial photographs were used to validate our model results for the retreating glacier from 1945 to 2003. Major changes in the length, surface altitude, and surface velocity of glaciers can be derived using stereophotogrammetric techniques. The aerial photographs used in this study were acquired on 11 dates between 1945 and 2003 (see Table 1).

[18] To be able to compare the geometry of the glacier at the different acquisition dates, the photographs needed to be orthorectified. Orthorectification corrects for geometrical distortions caused by relief displacement and lens properties. In this process also a digital elevation model (DEM) is created for each stereo pair. Leica Photogrammetry Suite (LPS, Leica Geosystems) was used for DEM extraction and orthorectification. This technique provides orthophotos with a ground resolution of $0.70 \mathrm{~m}$ and DEMs with a resolution of $5.0 \mathrm{~m}$. Ground control points (GCPs) were acquired from scanned and rectified maps (Table 2) of approximately the same date as for the stereo pair. All DEMs and orthophotos were projected into the same coordinate system. Figure 1 shows four orthorectified aerial photographs from different years.

[19] A curvilinear coordinate system along the flow line was used to ease interpretation. In a Geographical Information System (GIS), a node was placed every $200 \mathrm{~m}$ along the flow line. Around this node, the average surface elevation for each data set was calculated from the extracted DEMs within a circle with a radius of $100 \mathrm{~m}$ (Figure 6). The same was done for the bedrock topography. The difference gives the ice thickness (Figure 7a). A mean value of $q=$ 0.09 was obtained by applying the frontal ice thickness and 

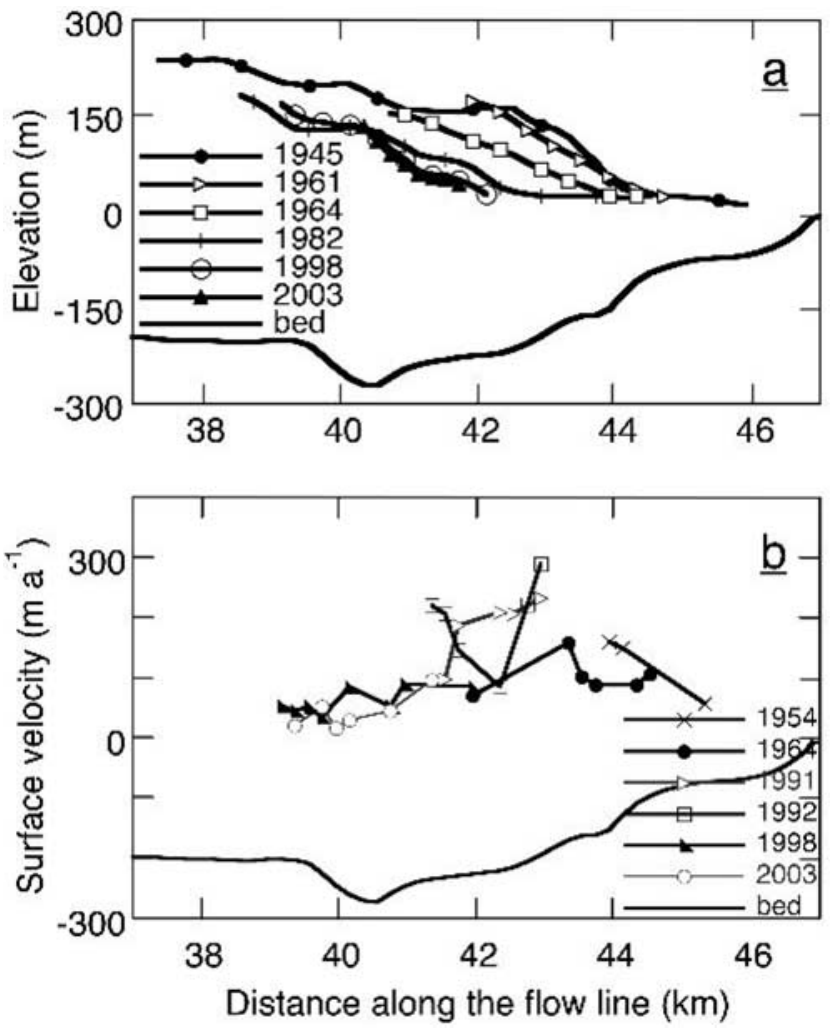

Figure 7. (a) Observed surface elevations and (b) observed ice surface velocities along the central flow line at the glacier front from 1945 to 2003.

the water depth for different years in the flotation equation (7). The surface velocity was calculated by correlating volcanic ash or debris layers at the surface of the glacier between different years (Figure $7 b$ ). The result barely shows an increase in the surface velocity at the glacial front. The glacier length for different dates can be measured from the orthophotographs by width averaging it along the glacier ice front (Figure 8).

\section{Results}

\subsection{Model Results}

[20] Starting with ice-free conditions, the model simulates glacier growth at higher elevation, followed by advance to the coastline. Figure 4 (section 3) presents the evolution of the simulated glacier surface in time while the glacier advances. A positive net mass balance forces the glacier to advance steadily during a period of 440 years (Figure $9 \mathrm{~b}$ ) and constitutes a proper initial surface profile to start the retreating scenario (Figure 4c). Figure 9a represents the evolution of glacier length in time. The glacier grows until it nears the sea, reaching a maximum length of $47 \mathrm{~km}$ at $T_{1}$. The terminal position is stable for the first three decades after reaching its maximum extent; however, the glacier is thinning owing to the negative mass balance.

[21] The glacier experiences calving once the terminal position moves backward. During the retreat, no sedimentation is considered in the model; therefore the glacier calves into the lake. The mass balance forcing during the retreat is modified in the model by using $E$ from the time of the maximum glacier extent $\left(T_{1}\right)$ until the present time $\left(T_{2}\right)$ and a constant $E=1100 \mathrm{~m}$ for the future (Figure 9b). The model calculations were carried out by applying the calving models discussed in section 1 (the flotation and the water depth model).

[22] The glacier retreat as simulated with the water depth model and the flotation model are shown in Figures 10a and $10 \mathrm{~b}$, respectively. The time interval between two surface profiles is five years. In the flotation model, if the glacier terminates in shallow water, the frontal thickness is large enough to satisfy the flotation criterion; therefore calving hardly occurs. In the water depth model, however, the calving rate is a linear function of water depth and produces a calving flux, even in shallow water. Therefore, at the beginning of the retreating scenario, the glacier modeled with the water depth criterion retreats faster than the glacier modeled with the flotation criterion (Figure 9a). As the glacier terminus gets into deeper water, the frontal thickness becomes too small to satisfy the flotation criterion, thus the terminus position must jump back to the location where the thickness is large enough. In this way, the glacier in the flotation model undergoes a rapid sudden retreat, whereas the water depth model provides a gradual increase in retreat rate as the frontal water depth increases (Figure 10).

\subsection{Comparison of the Model Results and Observations}

[23] Figure 11 shows the simulated and observed glacier length variation from 1920 until 2020. There is good agreement between the result of the water depth model (solid line) and the observed glacier length from 1945 to 2003 (open circles), whereas the flotation model (dashed line) produces a slower retreat, followed by an accelerated retreat as the glacier gets into the deeper water (Figure 10b).

[24] The simulated glacier surface profiles, with a time interval of five years between the profiles, are depicted for the water depth model and the flotation model in Figures $12 \mathrm{a}$ and $12 \mathrm{~b}$, respectively. The simulated ice thickness (Figure 12a) corresponds to the observed ice thickness (Figure 7a) fairly well. Nevertheless, the concave shape of the surface seen in the observed profiles is not reproduced by the model. The different profile shape is a result of the simple treatment of the basal sliding in the model. A more refined treatment of the basal sliding (considering the effect of the basal water pressure) may provide higher sliding velocities at the glacier front and the higher frontal velocities enable the model to maintain a concave profile at the terminus. The evolution of the glacier surface for the flotation model (Figure 12b) does not accord with the observations since it has experienced a sudden jump to the other side of the basal depression.

[25] Figure 13 shows the simulated ice surface velocities. The water depth model calculates an approximate terminus velocity of between $200-400 \mathrm{~m} \mathrm{yr}^{-1}$, which is in good agreement with the observed velocities derived from the aerial photography (Figure $7 \mathrm{~b}$ ). The simulation with the flotation model is not shown because of the dramatic retreat in the vicinity of the basal depression.

[26] Two additional model runs were performed to examine the sensitivity of the modeled retreat with the flotation model to the choice of the critical height above buoyancy. From the observed frontal thickness, a mean 

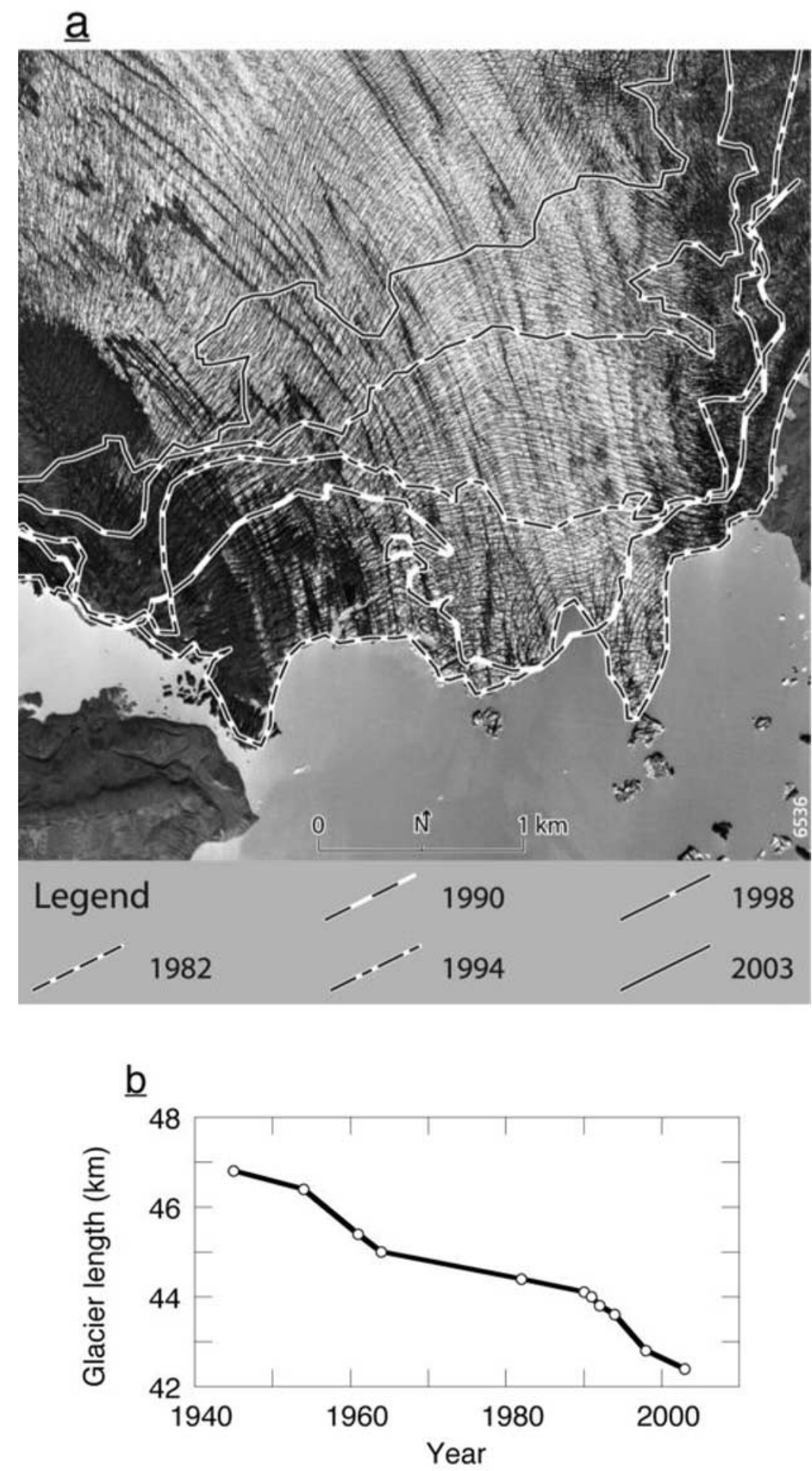

Figure 8. (a) Selected Breidamerkurjökull terminus positions from 1982-2003. (b) Glacier length variation in time (calculated by width averaging it along the terminus.)

value of 0.09 for $q$ in the flotation equation (7) was estimated. Figure 14 shows the simulated glacier length for a slightly larger $q=0.11$ and a smaller $q=0.06$. Although the smaller $q$ leads to a smaller mass loss by calving, and the larger $q$ provides a larger mass loss, the differences are not significant. In all runs, the glacier experienced an unrealistic rapid retreat, almost at the same location; varying q only shifted the onset of the rapid retreat in time. 

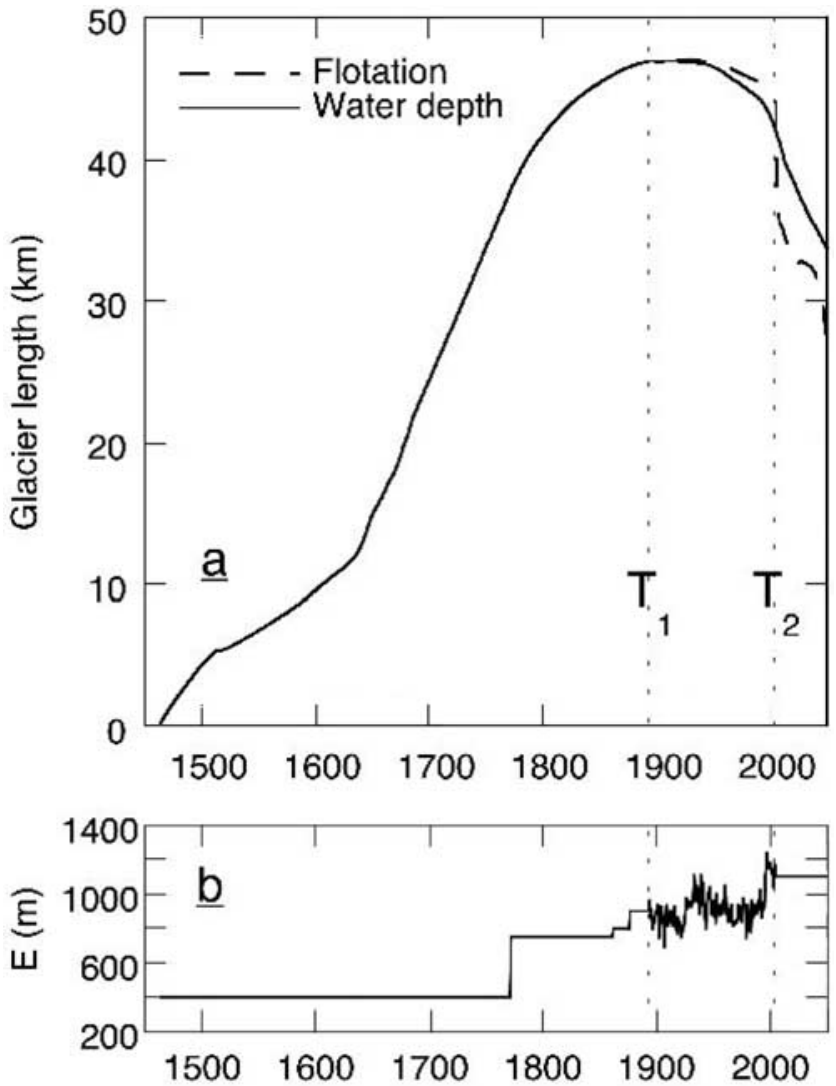

Time (a)

Figure 9. (a) Simulated evolution of the glacier length in time. (b) Equilibrium line altitude used in the model to simulate advance and retreat of the glacier. The time that the glacier reaches its maximum extent and the present time are indicated by $T_{1}$ and $T_{2}$, respectively.

\subsection{Future Prediction}

[27] According to the comparison made above, the water depth model produces a more realistic retreat history than the flotation model. We therefore carried out model runs with the water depth model to predict the glacier's future behavior. We applied three different values of $E: E=1100 \mathrm{~m}$ for the present climate, $E=1200 \mathrm{~m}$ for a warmer climate, and $E=1000 \mathrm{~m}$ for a colder climate. The results (Figure 15)

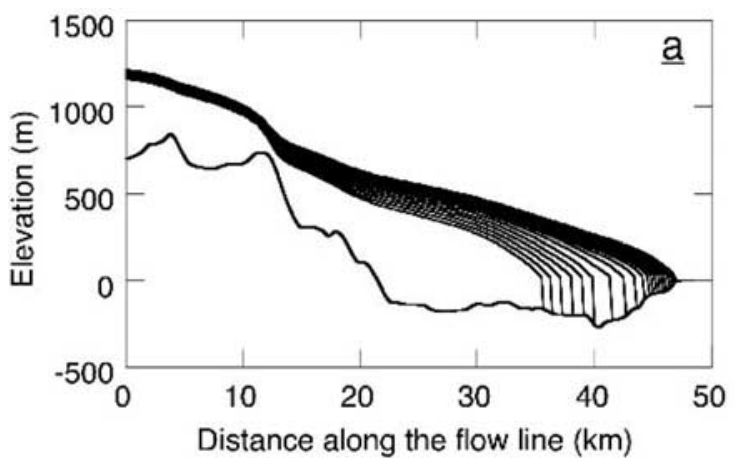

show that the retreat rate in all three scenarios decreases or increases as the frontal water depth becomes shallower or deeper, respectively. The glacier would retreat out of the lake after 105 years assuming the present value of $E(L=$ $21600 \mathrm{~m}$, Figure 3a), after 95 years for $E=1200 \mathrm{~m}$, and after 125 years for $E=1000 \mathrm{~m}$.

\section{Discussion and Conclusion}

[28] A series of aerial photos covering the front part of Breidamerkurjökull exists for 11 dates from 1945 to 2003. We used data acquired from these photographs to validate our modeling results. These photogrammetric methods are suitable for obtaining changes in length, surface altitude, and surface velocity. Nevertheless, several inaccuracies may have been introduced during the process of DEM extraction and orthorectification for the validation data set. Geometrical inaccuracies may have resulted from distortions caused by the scanning device used for the topographical maps and the aerial photographs. Collection of ground control points ( \pm 40 points) was restricted by the lack of features recognizable in both the maps and the aerial photographs. As only the areas exposed by the retreating glacier could be used, the GCPs were not evenly distributed over the photographs. This made accurate triangulation difficult. Conversions between projections may also have caused inaccuracies. As a rule, an accuracy of $10 \mathrm{~m}$ for both horizontal and vertical changes can be expected, which is much smaller than changes in glacier length and glacier surface altitude between dates of the photographs. The calculation of surface velocity by measuring vectors of corresponding ash layers in different years was not easy as the geometry of the ash layers had changed due to shearing motion at the glacier surface. Displacement of the observed ash layers on the photographs are also affected by the three-dimensional structure of the layers and the amount of surface ablation. A range of $30^{\circ}-60^{\circ}$ for the tilt angle of the layers with the glacier surface (D. Benn, unpublished data, 2006) and an average surface lowering of $5 \mathrm{~m} \mathrm{yr}^{-1}$ yield an underestimation of $3-9 \mathrm{~m} \mathrm{yr}^{-1}$ in the velocity measurements.

[29] It is known that Breidamerkurjökull did not advance gradually in response to climate change, but underwent a series of surges [Björnsson et al., 2003; Adalgeirsdottir, 2003; Evans and Twigg, 2002; Björnsson, 1996]. Simulating the glacier surges is beyond the capability of this model.

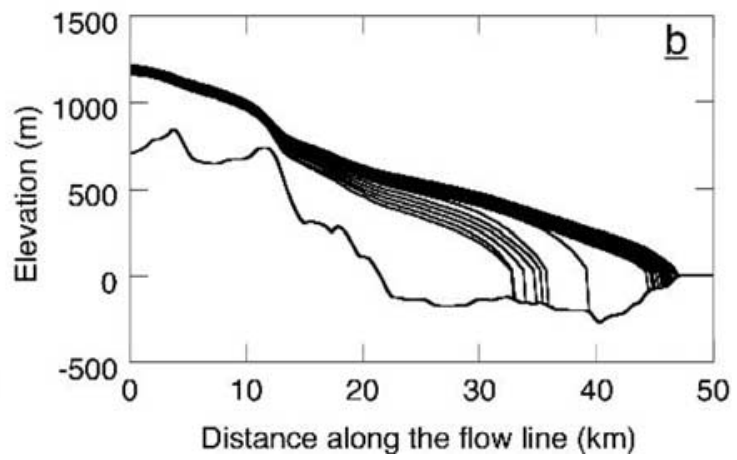

Figure 10. Evolution of the glacier surface during the phase of retreat for(a) the water depth model and (b) the flotation model. The time interval between profiles is 5 years. 


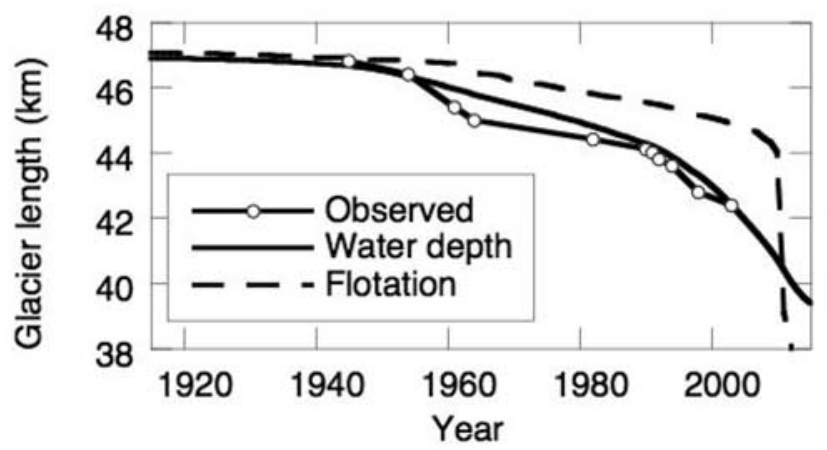

Figure 11. Retreat of Breidamerkurjökull from 1920 until 2002, modeled length variation with the flotation model (dashed line) and the water depth model (solid line). The open circles indicate the observed glacier length from the aerial photographs from 1945 to 2003 .

Our model simulates a continuous advance by utilizing a synthetic mass balance forcing to provide a proper initial glacier surface for the retreat scenario.

[30] The frontal sedimentation is an important control on terminus fluctuation of tidewater glaciers [Boulton, 1970; Alley, 1991; Powell, 1991]. Push moraine banks at the glacier terminus produce restraining forces, which may affect the ice flow [Van der Veen, 1997; Fischer and Powell, 1998]. In the present model, during the glacier advance, we assumed a sedimentation bank in front of the glacier which levels off the lake basin with the sea level. However, we left out the restraining forces associated with this sedimentation bank in the model calculations. The model simulation for
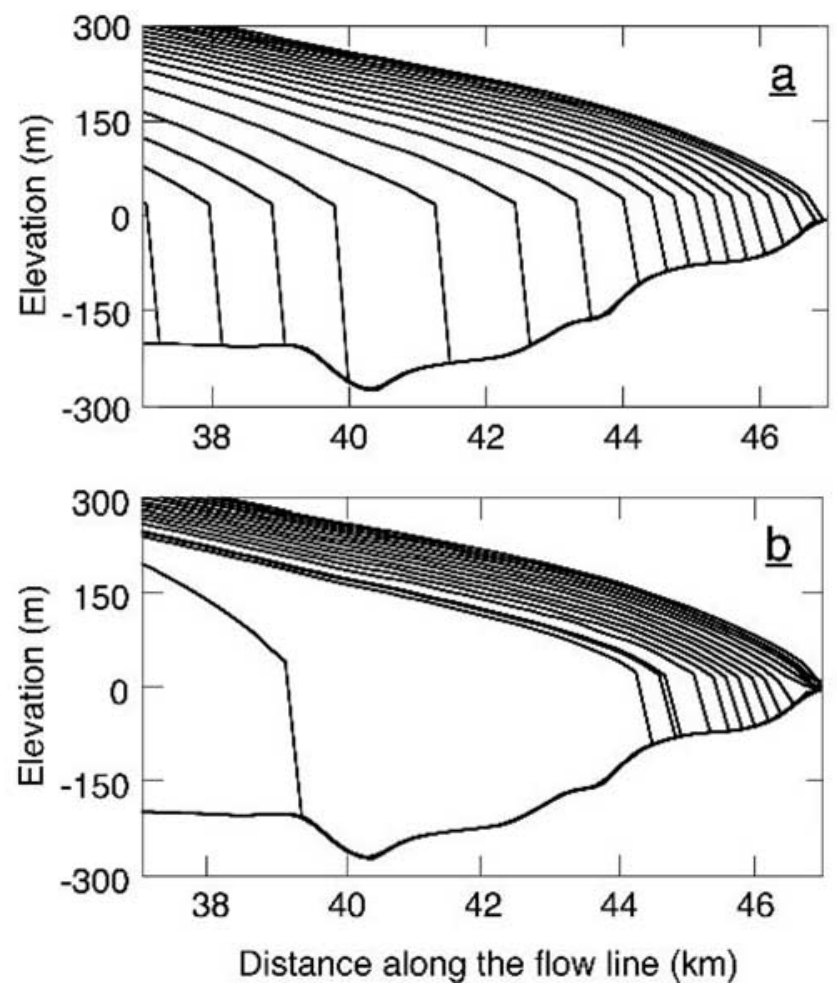

Figure 12. Simulated glacier surface at the glacier front with (a) the water depth model and (b) the flotation model.

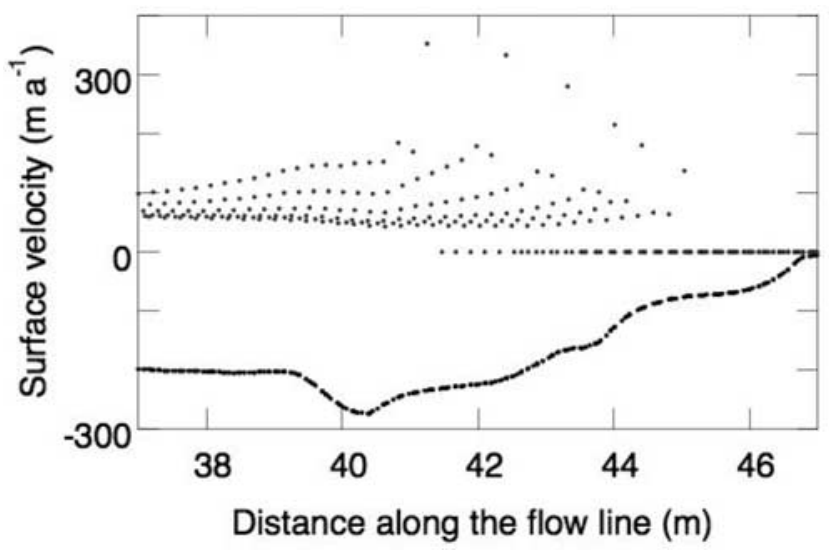

Figure 13. Simulated (water depth model) glacier velocity along the central flow line at the glacier front.

the glacier retreat does not consider any sedimentation or the formation of a submarine moraine shoal as the glacier retreats fairly rapidly and becomes detached from any support structure possibly created through sedimentation.

[31] Van der Veen [1996] argued that the water depth model is relevant only for glaciers that are almost in steady state or moving slowly. Vieli et al. [2001] performed a numerical study on a small and slowly flowing tidewater glacier, Hansbreen in Spitsbergen. They suggested that the flotation model is able to simulate the rapid retreat and slow advance of the glacier better than the water depth model. We have taken a different approach and compared both calving schemes by applying a numerical model to Breidamerkurjökull, which is a rather large and fast tidewater glacier with a basal depression of $300 \mathrm{~m}$. The results indicate that the flotation model fails to simulate the observed glacier retreat into very deep water (deeper than $100 \mathrm{~m}$ ), whereas the water depth model is able to reproduce the observed glacier length variation during the retreat into deep water. The calving criterion of the flotation model causes the glacier to lose a huge amount of mass in an unrealistically short time when it moves into very deep water.

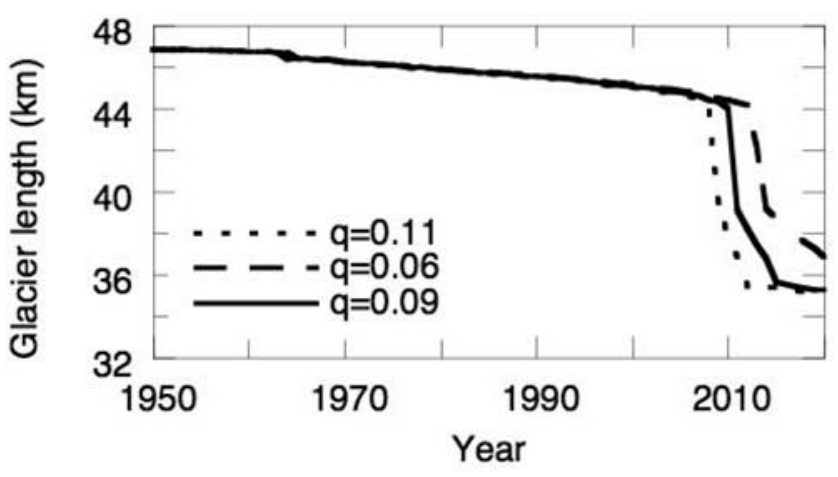

Figure 14. Retreat phase simulated with the flotation model for different values of critical thickness. The solid line represents the modeled glacier length for $q=0.09$, presented in Figure 10. The dashed and dotted lines show the modeled glacier length for a smaller critical thickness $(q=0.06)$ and a larger critical thickness $(q=$ $0.11)$, respectively. 


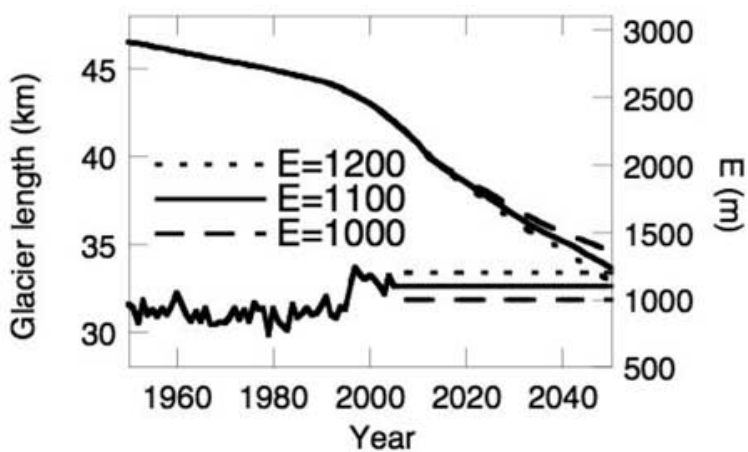

Figure 15. Predicted glacier length and equilibrium line altitude for the next 100 years, for three scenarios: continuation of the present (solid line), a warmer climate (dotted line), and a cooler climate (dashed line).

[32] Our findings thus do not support the hypothesis that the flotation model can explain the behavior of tidewater glaciers properly. We believe that the flotation model is able to reproduce the glacier length variation better than the water depth model only for glaciers that terminate in shallow water, as was shown by Vieli et al. [2001]. However, for glaciers terminating into very deep water, we recommend the water depth model as a tool to represent the glacier's behavior.

[33] Björnsson et al. [2001] calculated a constant retreat rate for the next 70 years and predicted that Breidamerkurjökull would retreat from the lake basin after $\sim 200$ years. Our water depth model calculations suggest that Breidamerkurjökull will retreat the $20 \mathrm{~km}$ out of the lake basin after $\sim 100$ years in the present-day climate. Note that our model calculations assume a constant mass balance function of height and the future variation in mass balance is not considered in the model prediction.

[34] Acknowledgments. The authors are grateful to Helgi Björnsson and Finnur Pálsson for their personal communications and for providing data. We also thank M. J. Zeylmans Van Emmichoven for his support and facilitating GIS and photogrammetry software.

\section{References}

Adalgeirsdottir, G. (2003), Flow dynamics of Vatnajökull ice cap, Iceland, 178 pp., Ph.D. thesis, Versuchsanst. fr Wasserbau, Hydrol. und Glaziol., Zürich, Germany.

Alley, R. B. (1991), Sedimentary processes may cause fluctuations of tidewater glaciers, Ann. Glaciol., 15, 119-124.

Björnsson, H. (1996), Scales and rates of glacial sediment removal: A $20 \mathrm{~km}$ long, $300 \mathrm{~m}$ deep trench created beneath Breidamerkurjökull during the Little Ice Age, Ann. Glaciol., 22, 141-146.

Björnsson, H., F. Palsson, M. T. Gudmundsson, and H. H. Haraldsson (1998), Mass balance of western and northern Vatnajökull, Iceland, 1991-1995, Jökull, 45, 35-38.

Björnsson, H., F. Palsson, and S. Gudmundsson (2001), Jökulsárlón at Breidamerkursander, Vatnajökull, Iceland: 20th century changes and future outlook, Jökull, 50, 1-18.

Björnsson, H., F. Palsson, and H. H. Haraldsson (2002), Mass balance of Vatnajökull (1991-2001) and Langjökull (1996-2001), Iceland, Jökull, $51,75-78$.

Björnsson, H., F. Palsson, O. Sigurdsson, and G. E. Flowers (2003), Surges of glaciers in Iceland, Ann. Glaciol., 36, 82-90.
Boulton, G. S. (1970), On the deposition of subglacial and melt-out tills at the margins of certain svalbard glaciers, J. Glaciol., 9, 231-245.

Boulton, G. S., P. W. V. Harris, and J. Jarvis (1982), Stratigraphy and structure of a coastal sediment wedge of glacial origin inferred from sparker measurements in glacial lake Jökulsárlón in souteastern Iceland, Jökull, 32, 37-47.

Brown, C. S., M. F. Meier, and A. Post (1982), Calving speed of Alaska tidewater glaciers, with application to Columbia Glacier, U.S. Geol. Surv. Prof. Pap., 1258-C.

Budd, W. F., P. L. Keage, and N. L. Blundy (1979), Empirical studies of ice sliding, J. Glaciol., 23, 157-170.

De Ruyter de Wildt, M. S. (2002), Satellite-retrieval and modeling of glacier mass balance, 129 pp., Ph.D. thesis, Utrecht Univ., Utrecht, Netherlands.

Dowdeswell, B. J., et al. (1997), The mass balance of circum-Arctic glaciers and recent climate change, Quat. Res., 48, 1-14.

Evans, D. J. A., and D. R. Twigg (2002), The active temperate glacial landsystem: A model based on Breidamerkurjökull and Fjallsjöll, iceland, Quat. Sci. Rev., 21, 2143-2177.

Fischer, M. P., and R. D. Powell (1998), A simple model for the influence of push-morainal banks on the calving and stability of glacial tidewater termini, J. Glaciol., 44, 31-41.

Glen, J. W. (1955), The creep of polycrystalline ice, Proc. R. Soc. Lonson, $228,519-538$.

Meier, M. F. (1994), Columbia Glacier during rapid retreat: Interactions between glacier flow and iceberg calving dynamics, Proceedings, Workshop on the Calving Rate of West Greenland Glaciers in Response to Climate Change, edited by N. Reeh, pp. 63-83, Dan. Polar Cent., Copenhagen.

Meier, M. F. (1997), The iceberg discharge process: Observations and references drawn from the study of Columbia Glacier, in Calving Glaciers: Report of a Workshop, February 28-March 2, 1997, BPRC Rep. 15, edited by C. J. Van der Veen, pp. 109-114, Byrd Polar Res. Cent., Ohio State Univ., Columbus.

Meier, M. F., and A. Post (1987), Fast tidewater glaciers, J. Geophys. Res., 92, 9051-9058.

Nick, F. M., and J. Oerlemans (2006), Dynamics of tidewater glaciers: comparison of three models, J. Glaciol., 52(177), 183-190.

Oerlemans, J. (2001), Glaciers and Climate Change, 147 pp., A. A. Balkema, Brookfield, Vt.

Paterson, W. S. B. (1981), The Physics of Glaciers, Elsevier, New York.

Pelto, M. S., and C. R. Warren (1991), Relationship between tidewater glacier calving velocity and water depth at the calving front, Ann. Glaciol., 15, 115-118.

Powell, R. D. (1991), Grounding-line systems as second-order controls on fluctuations of tidewater termini of tenperate glaciers, Spec. Pap. Geol. Soc. Am., 261, 75-93.

Smith, G. D. (1978), Numerical Solution of Partial Differential Equations: Finite Difference Methods, 2nd ed., 304 pp., Clarendon, Oxford, U.K.

Van der Veen, C. J. (1986), Longitudinal stresses and basal sliding: A comparative study, in Dynamics of the West Antarctic Ice Sheet, edited by C. J. Van der Veen and J. Oerlemans, pp. 223-248, Springer, New York.

Van der Veen, C. J. (1996), Tidewater calving, J. Glaciol., 42, 375-385.

Van der Veen, C. J. (1997), Backstress: What it is and how it affects glacier flow, in Calving Glaciers: Report of a Workshop, February 28-March 2, 1997, BPRC Rep. 15, edited by C. J. Van der Veen, pp. 173-180, Byrd Polar Res. Cent., Ohio State Univ., Columbus.

Van der Veen, C. J. (1999), Fundamentals of Glacier Dynamics, 460 pp., A. A. Balkema, Brookfield, Vt.

Van der Veen, C. J., and I. Whillans (1993), Location of mechanical controls on Columbia Glacier, Alaska, U.S.A., prior to its rapid retreat, Arct. Alp. Res., 25, 99-105.

Vieli, A., M. Funk, and H. Blatter (2001), Flow dynamics of tidewater glaciers: A numerical modelling approach, J. Glaciol., 47, 595-606.

F. M. Nick and J. Oerlemans, Institute for Marine and Atmospheric Research Utrecht, Princetonplein 5, NL-3584 CC Utrecht, Netherlands. (f.m.nick@phys.uu.nl)

J. van der Kwast, Department of Physical Geography, Faculty of Geosciences, Utrecht University, Heidelberglaan 2, NL-3584 CS Utrecht, Netherlands. 